\title{
STЕМ-ОСВІТА ЯК ІНСТРУМЕНТ РЕАЛІЗАЦІЇ ІНТЕГРОВАНОГО ВИВЧЕННЯ ПРИРОДНИЧО-МАТЕМАТИЧНИХ ДИСЦИПЛІН
}

Сучасні потреби світової спільноти викликані глобальними змінами сочіально-економічних процесів, які пов'язані зі стрімким розвитком інформаційних мереж, нової енергетики, нанотехнологій, робототехніки та біотехнологій. $У$ зв'язку з иим, забезпечення підготовки висококваліфікованих винахідливих фахівців є головною перспективою для прогресивного розвитку науки та технологій. Зазначені сфери потребують від фахівців використання комплексних знань із таких освітніх галузей, як природничі науки, математика, інженерія, програмування та технології. Наголошується на актуальності дослідження STEM-орієнтованого навчання для розвитку школярів у сучасному науково-технічному напрямі. Як загальновідомо, STEM-освіта - ие світова абревіатура: природничі науки (Science), технології (Technology), технічна творчість (Engineering) ma математика (Mathematics). У статті пояснюється необхідність додання компоненту Art (мистецттво) до иісєї абревіатури. Проведено аналіз понять «інтеграиія», «STEM-освіта», «STEAM-освіта» ma «STEM-проєкт». Відзначаються перспективи для їх використання в навчально-виховному прочесі закладів загальної середньої освіти. Розглянуто законодавчу нормативно-правову базу щодо стану розвитку STЕМ-навчання та актуальні питання необхідності реформування освітньої системи в Україні. 3'ясовано, щзо інтеграція є провідним принциипом STЕM-освіти, оскільки сприяє формуванню нерозривно зв'язаної та єдиної системи знань. Встановлено, щз ізольованість викладання навчальних предметів та їх роз'єднаність не зможе забезпечити належний розвиток у напрямі комплексної природничо-математичної освіти. Акцентовано увагу на необхідності у міждисииплінарному підході та практико-орієнтованому навчанні науково-освітньої системи STEM для усунення розриву між теоретичними знаннями та їх практичним втіленням. Наведено приклад STEAM-проєкту «Благоустрій рідного краю». Проаналізовано його можливості для міждисциплінарного поступу та розвитку досліднищьких навичок здобувача середньої освіти.

Ключові слова: інтеграчія, STEM-освіта, STEM-проєкт, STEAMосвіта, природничо-математичне навчання. 
Matviichuk Yu. Yu. STEM education as a tool of implementation of integrated study of natural and mathematical disciplines. The current needs of the world community are caused by global changes in socio-economic processes, which are associated with the rapid development of informational networks, new energetics, nanotechnology, robotics and biotechnology. In this regard, providing training for highly skilled resourceful professionals is a major prospect for the progressive development of science and technology. Mentioned areas require professionals to use comprehensive knowledge in educational fields such as science, mathematics, engineering, programming and technology. Emphasis is placed on the relevance of the study of STEM-oriented learning for the development of students in the modern scientific and technical direction. STEM education is a well-known world abbreviation: science, technology, engineering and mathematics. The article explains the need to add Art component to this abbreviation. The analysis of the concepts "integration", "STEM education", "STEAM education" and "STEM project" has been performed. Prospects for their use in the educational process of secondary education are noted. The legal framework on the state of development of STEM education and current issues of the need to reform the education system in Ukraine are considered. Integration has been found to be a guiding principle of STEM education, as it contributes to the formation on an inextricably linked and unified system of knowledge. It has been established that the isolation of teaching subjects and their separation will not be able to ensure proper development in the direction of integrated science and mathematics education. Emphasis is placed on the need for an interdisciplinary approach and practice-oriented learning of the scientific and educational system STEM to bridge the gap between theoretical knowledge and their practical implementation. An example of the STEAM project "Improvement of the native land" is given. Its possibilities for interdisciplinary progress and development of research skills of the applicant of secondary education are analyzed.

Keywords: integration, STEM education, STEM project, STEAM education, scientific-mathematical education.

Вступ. Стрімкий інформаційний і технологічний розвиток суспільства та обмеженість людських можливостей - це суперечність освіти, яку намагаються вирішити в академічній спільноті. Глобалізація та орієнтація на діяльнісну і ціннісну парадигму суспільства обумовлює нові виклики перед здобувачем освіти. Просте набуття певної суми знань із навчальних предметів не відповідає соціальним запитам. Фундаментальними для висококваліфікованого спеціаліста є: здатність нестандартно мислити у нових ситуаціях; навички розробки та проведення експерименту; вміння аналізувати отримані дані, обгрунтовувати висновки та самостійно втілювати теоретичні знання в життєвих ситуаціях. Саме STEM-освіта охоплює розвиток всіх зазначених якостей. 
Питання реалізації окремих аспектів STЕМ-освіти досліджували В. Гайда І. Савченко, М. Бойченко, І. Данильченко, О. Андрєєв, Н. Джелалія, С. Дембіцька, М. Джелалія, І. Стеценко, О. Янковська, О. Патрикеєва та інші. Перспективи та суперечності STEAM-освіти у своїх працях розглядають Н. Морзе, О. Коршунова, С. Галата, О. Стрижак, О. Патрикєєва, І. Сліпухіна та інші. Можливості STEM-навчання для розвитку та мотивації здобувачів освіти до науково-дослідної діяльності у своїх доробках розкривають С. Гальченко, Т. Андрущенко, К. Гуляєв, Н. Гончарова, Л. Ніколенко, Е. Клімова, В. Камишин, Р. Норчевський, Є. Шаповалов, О. Стрижак, I. Чернецький та інші.

Отже, українська освіта знаходиться на шляху інноваційного розвитку: розробляються концепції, рекомендації, методичні розробки, проводяться дослідження та відкриваються центри, які стосуються STEM-освіти. Однак, питання реалізації ідей інтегрованого природничо-математичного навчання у контексті STEM-освіти, попри активне обговорення в академічній спільноті, $\epsilon$ досить складним та потребує більш досконалого вивчення.

Мета та завдання. Метою статтіє вивчення можливостей STEMосвіти для інтеграції природничо-математичних дисциплін. Досягнення зазначеної мети обумовлено виконанням таких завдань:

- 3'ясувати сутність понять «інтеграиія», «STEM-освіта», «STEMпроєкт», «STEAM-освіта»;

- на основі аналізу законодавчої нормативно-правової бази визначити рівень розвитку STЕМ-освіти в сучасній Україні;

- навести приклад STEAM-проєкту «Благоустрій рідного краю» та проаналізувати його можливості для міждисциплінарного розвитку здобувача загальної середньої освіти.

Методи дослідження. У дослідженні використовувались такі загальнонаукові методи, як: аналіз (законодавчої, психолого-педагогічної літератури, інформаційних джерел із проблеми дослідження), синтез, порівняння, систематизація та узагальнення матеріалу (для визначення сутності основних понять дослідження).

Результати. Як свідчить вивчення та узагальнення науковопедагогічних матеріалів,в основу створення та розвитку різноманітних новітніх технологій покладено знання природничо-математичних дисциплін на їх сучасному рівні. Тож, ізольованість викладання навчальних предметів та їх роз'єднаність не зможе забезпечити належний розвиток у напрямі комплексної природничо-математичної освіти. Це ускладнює формування цілісних зв'язків між об'єктами, що вивчаються, та заважає формуванню міжпредметної компетентності. Тому, необхідною ланкою для якісної 
реалізації нових запитів та тенденцій суспільства $\epsilon$ забезпечення комплексного міждисциплінарного підходу на основі інтеграції та взаємозв’язку навчальних предметів як єдиного цілого. STEM-освіта достатньо нове явище в освіті, що потребує певної уваги.

Як свідчить вивчення останніх публікацій, розширення та доповнення законодавчої нормативно-правової бази, розроблення концепцій, положень та ключових ідей, методичних порад стосовно реформування середньої школи й упровадження STEM-освіти в позашкільних установах та З3СО України відбувається на державному рівні.

Імплантація STEM-освіти в навчальний процес відбувається у відповідності з Законами України «Про освіту», «Про загальну середню освіту», «Про наукову та науково-технічну діяльність», «Про інноваційну діяльність», «Про позашкільну освіту». Також було представлено план заходів стосовно реалізації STEM-освіти в Україні протягом 2016-2018 років, затверджений МОН України 05 травня 2016 року. Згідно з протоколом №7 від 16.05.2017 було створено робочу групу з питань поширення STEM-освіти. Згодом, відповідно до наказу МОН України від 17.05.2017 року (№ 708), ухвалено дозвіл «Щодо проведення дослідно-експериментальної роботи на всій території України за темою «Науково-методичні засади створення та функціонування Всеукраїнського науково-методичного віртуального STEMцентру» на 2017-2021 роки».

Концепція модернізації середньої освіти «Нова українська школа», котра схвалена розпорядженням КМ України 14.12.2016 року (№ 988), теж передбачає забезпечення міждисциплінарного інтегрованого підходу i підвищення мотивації учнів до засвоєння природничих предметів за рахунок STEM.

У 2017 році відділ STEM-освіти Інституту модернізації змісту освіти, видавничий дім «Освіта», Університет менеджменту освіти розпочали розробку соціального інноваційного проєкту в галузі освіти - «Web-STEMшкола», в основу якого покладено Український проєкт «Якість освіти». Школа $є$ унікальним простором нового формату, який сприяє спільному навчанню, спілкуванню, обміну та вивченню найкращого вітчизняного i зарубіжного досвіду, знайомству з сучасними новаторами освіти.

Не менш важливим підтвердженням необхідності реформування загальної середньої освіти на державному рівні стали результати міжнародного дослідження якості освіти PISA-2018. Згідно з якими, 36\% українських учнів не досягли базового рівня математичної та 26,4\% природничо-наукової грамотності. У порівнянні з країнами ОЕСР, показники України гірші на 12,1\% та 5,4\% відповідно (Mazorchuk \& al, 2019). Тобто, 
третина учасників дослідження мали проблеми з використанням алгоритмів виконання простих завдань, не розглядаючи розв’язання нестандартних та прикладних задач.

Отже, необхідним для сучасного покоління є забезпечення формування навичок системного математичного мислення та посилення їх практичного спрямування. Зазначене вимагає від суспільства i держави здійснення підтримки останніх тенденцій світового досвіду та активного дослідження й аналізу закордонних інновацій 3 метою подальшого їх впровадження. У контексті сказаного, актуальним $є$ дослідження STEM-орієнтованого навчання для розвитку школярів у сучасному науково-технічному напрямі.

Акронім STEM введено у 2001 році науковими адміністраторами в Національному науковому фонді США (NSF). Спочатку, для характеристики інтеграції знань та навичок у сферах кар'єри, в яких вони об'єднуються, використовували абревіатуру SMET. Далі, Джудіт Рамалі замінила слова, щоб сформувати нову абревіатуру. I сьогодні STEM розшифровується так: S - science (природничі науки), T - technology (технологіi), E - engineering (інженерія або технічну творчість), M - mathematics (математика) (Hallinen, 2015).

STEM-освіта бере свої витоки 32009 року і пов’язана з програмою «Educate to Innovate» (США). У документах Департаменту освіти США, наголошується, що STEM передбачає «освіту для глобального лідерства», котра спрямована на формування особливого «підходу до світу, критичного шляху мислення, навичок дослідження i взаємодії зі світом», так як досягнення в сучасному світі визначаються «не стільки тим, у чому ви обізнані, скільки тим, що ви можете зробити з тим, у чому ви обізнані» (Science, Technology, Engineering, and Math, including Computer Science, n. d.).

STEM-освіта - це сучасна науково-освітня система, в основу якої покладено трансдисциплінарний підход до навчання. Ця система спрямована на формування особистості науковця шляхом розвитку компетентностей, формування природничо-наукової картини світу, світогляду та життєвих цінностей. Курс на практичне застосування наукового, математичного, технічного та інженерного знання та вміння з метою розв'язання практичних проблем є обов'язковим елементом якісної підготовки та забезпечує їх подальше використання в професійній діяльності (Glossarii, n. d.).

Формування зазначених знань у нерозривно зв'язану та єдину систему забезпечує інтеграція, яка є провідним принципом STEM-освіти. Інтеграція передбачає координацію цілеспрямованого процесу об’єднання структурних елементів змісту освіти, засобів, методів та організаційних форм навчання, 
що сприяє виникненню нових якісних можливостей цієї цілісності, а також призводить до змін властивостей самих елементів (Sinopalnikova, 2010). У процесі інтеграції відбувається встановлення, систематизація та зміцнення зв’язків навчального матеріалу 3 різних галузей знань. Це сприяє продуктивному розумовому та творчому розвитку дитини. Процес інтеграції полягає не в простій комбінації матеріалу двох або більше предметів, а у формуванні нерозривно зв'язаної та єдиної інтегрованої системи між ними.

Інтеграція дозволяє проводити перегляд змісту освіти, навчального матеріалу і методологічних засад організації STEM-навчання, котре об’єднує дисципліни на базі міждисциплінарного практико-орієнтованого підходу для інтегрованого вивчення природничо-математичних дисциплін. Такий підхід забезпечує комплексне навчання учнів з метою розв'язання соціальних, економічних та науково-технологічних викликів сучасності (TeachingSTEM).

Дослідження свідчить, що метою STEM-освіти виступає цілеспрямоване створення зв'язків між навчальним середовищем та викликами сучасного світу в аспекті розвитку природних здібностей учня. Рівень отриманих навичок визначатиме успішну самореалізацію дитини як під час навчання, так і поза школою. У процесі навчання дитина не просто сприймає готові факти, а досліджує їх сама, генерує цікаві ідеї та відразу втілює їх у життя, вчиться планувати свою діяльність для реалізації цілі, виходячи з поставленого завдання і наявних можливостей (Proekt kontseptsii STEM-osvity v Ukraini, n. d.).

Формування вище зазначених здібностей та реалізація STEM-навчання може здійснюватися 3 використанням таких основних організаційних форм, як урок (заняття), фестиваль, курс, проєкт, квест, хакатон та інші, в яких діяльність вчителя та учнів здійснюється у встановленому порядку i в певному режимі (Polikhun, 2019). Кожна із зазначених форм має свої особливості організації, цілі та спрямування, але спільним є те, що навчання побудоване не навколо вчителя, а навколо досліджуваного питання. У даній статті більш детально розглянемо STEM-проєкт.

Зазначений проєкт - це групова навчально-пізнавальна, творча або ігрова діяльність учнів, яка має загальну мету, методи та засоби діяльності, спрямовані на досягнення загального результату. Проєкт передбачає інтеграцію трьох і більше STEM-дисциплін та надає можливість здобути та узагальнити знання на основі дослідницького пошуку в освітньому процесі (Polikhun, 2019). Учні не вивчають напрями вирішення проблеми з боку теоретичних аспектів, а йдуть до поставленої мети шляхом спроб та помилок. Оформлення проєкту супроводжується розвитком креативного та критичного мислення, діти вчаться генерувати ідеї та перегруповувати їх. 
Робота в групах готує учнів до співпраці та толерантності до чужих думок. Крім цього, використовуються спеціальні інструменти: онлайнконструктори, програми з комп'ютерної анімації та моделювання, робота 3 навчальними роботами-конструкторами тощо. Це надає можливість вийти за межі власного розуму та доповнити своє бачення через новітні технології наочності, що сприяє пізнавальній активності школярів.

Отже, у процесі впровадження STEM-проєкту в освітнє середовище необхідно керуватись такими принципами, як: інтеграція, науковість, розвиток, дослідницька та практична спрямованість, пізнавальна активність та комунікативність.

Для забезпечення всебічного розвитку дитини та рівномірного використання півкуль головного мозку, додається необхідність у розвитку творчих здібностей. Тож, вище згаданий акронім розширюється до STEAM, де A - Art (мистецтво). STEAM-освіта - це напрям креативного пізнання, який окрім природничо-математичних, інженерних, технічних дисциплін, включає творчі та художні дисципліни (промисловий дизайн, архітектура, індустріальна естетика тощо). Разом із тим, додавання літери «А» означає «All», тобто всі навчальні дисципліни для забезпечення комплексного вивчення однісї дисципліни через іншу, і навпаки (Glossarii, n. d.). Поєднання мистецтва 3 природничими науками дозволяє дитині сприймати навколишній світ із різних боків, усвідомлюючи його багатогранність.

Освіта в Україні знаходиться на шляху інноваційного розвитку. Враховуючи велику кількість концепцій, методологічних досліджень, методичних розробок та рекомендацій, які стосуються STEM-освіти, не кожна школа має достатнє матеріально-технічне забезпечення. Тому педагог має будувати навчальну діяльність у відповідності до наявних матеріальних ресурсів, використовувати можливості Online-середовища та власний креатив. Як приклад, розглянемо розробку STEAM-проєкту «Благоустрій рідного краю», використання якої можливе в будь-якому 33СО, що не має модернізованих STEM- лабораторій. Проєктом може керувати вчитель математики звичайної школи 3 додатковою консультацією від вчителів трудового навчання та біології.

\section{STEAM-проскт «Благоустрій рідного краю»}

Для кого: учні 8-9 класів.

Кількість дітей в групі: від 3 до 4 осіб.

Дисципліни: математика, інформатика, трудове навчання, образотворче мистецтво, біологія, екологія. 
Meта: організація творчого навчального середовища для розвитку дослідницьких навичок учнів та залучення їх до застосування набутих знань задля вирішення реальної ситуації з благоустрою рідного краю.

Реалізація наскрізних змістових ліній із математики: «Підприємливість і фінансова грамотність», «Громадянська відповідальність», «Здоров’я і безпека», «Екологічна безпека та сталий розвиток».

\section{Формулювання завдання для учнів.}

На рисунку (Рис.1) представлено план місцевого парку. Схематично зображено прямокутниками чотири зони для активного відпочинку жителів міста: зона 1 - спортивно-оздоровчий комплекс, зона 2 - майданчик із атракціонами, зона 3 - скейт-парк, зона 4 - дитячій майданчик.

Необхідно знайти загальну площу парку, довжину кожної зони та спільну ширину двох сусідніх зон, якщо: 1) загальна площа ділянки під зоною 1 та зоною 2 (на схемі їх зафарбовано) дорівнює $551 \mathrm{~m}^{2}$; 2) загальна площа ділянки під зоною 3 та зоною 4 (на схемі їх зафарбовано) дорівнює $220 \mathrm{~m}^{2}$.

Не зафарбована частина парку - це доріжки, їх розмір вказано на схемі.

3 урахуванням отриманих результатів, розробити: 1) схематичний рисунок парку відпочинку (паспорт об'єкту) із зазначенням всіх розмірів; 2) 3D-модель парку, використовуючи програмне забезпечення онлайн-сервісів; 3) реальний макет парку (зберігати масштаб).

Зауваження: варіативною частиною для учнів залишається ширина кожної зони в залежності від переконань групи та наповненості зони. Розмір доріжок між зонами залишається сталим.

До схеми, моделі та макету можна вносити корективи щодо наповненості. Можна додавати острівки з іншими зонами, газони, тротуари, клумби, кафе, озерце тощо. Головне не виходити за межі отриманої площі.

\section{Додаткові завдання.}

1) Озеленення парку. Скільки берез можна висадити по периметру парку з отриманою площею, якщо для його повноцінного розвитку необхідна відстань 4 метри між деревами? По кутам парку дерева висаджувати не можна.

Скільки кисню будуть виробляти дерева та скільки вуглекислого газу вони поглинатимуть? Як саме відбувається процес фотосинтезу? Чи можуть берези очищати повітря та покращувати його якість (досліди Джозефа Прістлі)? 
2) Забезпечення місиь для спокійного відпочинку. Скільки лавочок можна розмістити на доріжках парку, якщо відстань між ними має бути мінімум 2 м. По кутам парку лавочки розміщувати можна.

Скільки сміттєвих баків буде на доріжках парку, якщо вони мають стояти з обох боків кожної лавочки?

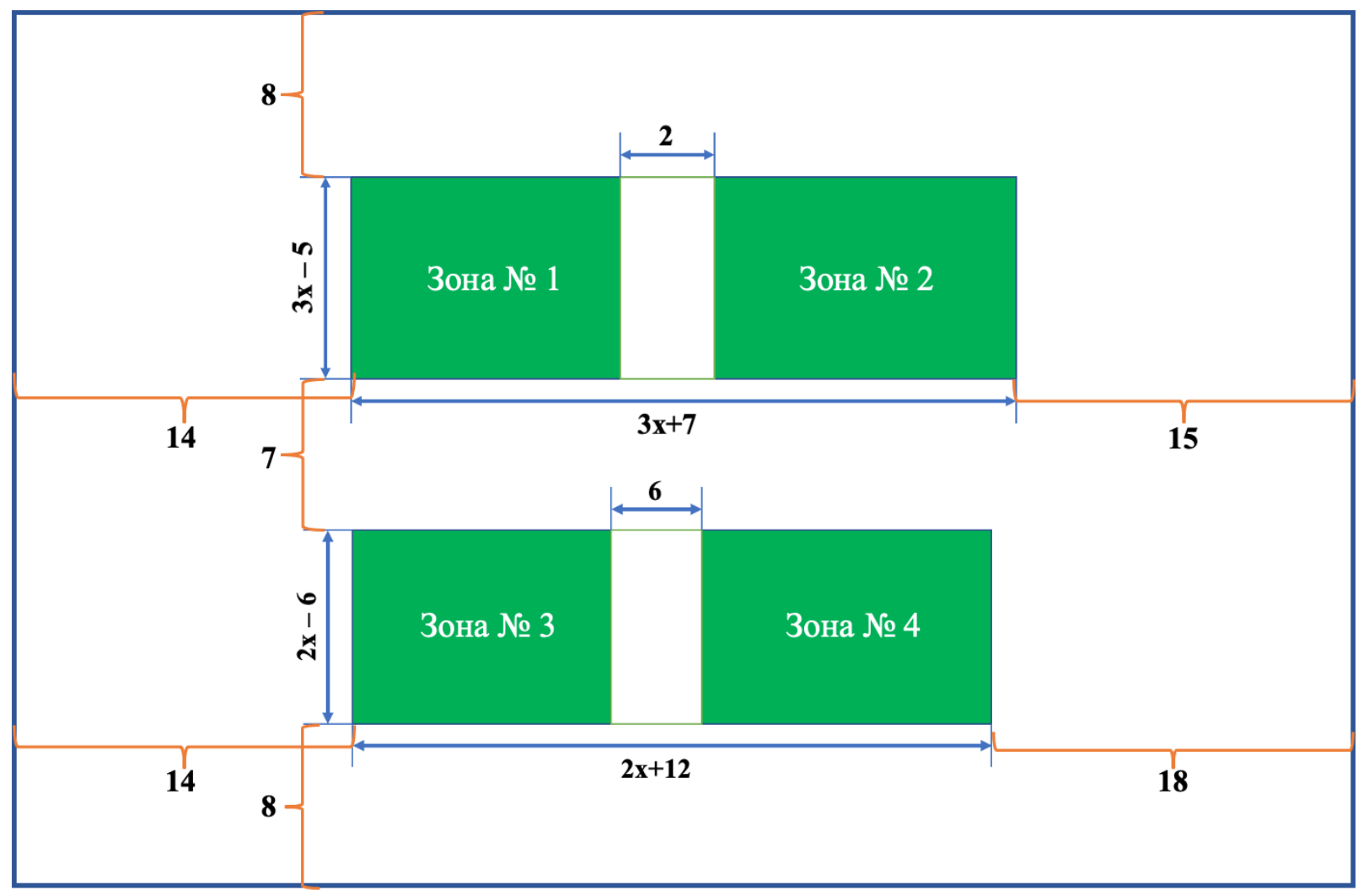

Рис. 1. Математична схема об'єкта по благоустрою міста

\section{Коментар до ходу розв'язку поставленого завдання.}

Математична складова. Для успішного розв'язку наочної задачі за представленою схемою (Рис. 1), учням необхідно було мати знання з теми «Площа многокутників» 3 курсу геометрії та теми «Квадратні рівняння» 3 курсу алгебри 8 класу. Програму предметів розміщена на офіційному вебсайті МОН України(Osvitni prohramy, n. d.).

Учні мали звернути увагу на те, що на рисунку лише довжину зон зазначено повноцінно, а ширина всіх чотирьох зон зазначена з урахуванням розділення їх доріжкою певної довжини. Отже, для того, щоб знайти невідомий коефіцієнт $x$, необхідно було скласти рівняння, використовуючи формулу площі прямокутника. Оскільки загальна площа ділянки під зоною 1 та зоною 2 (на схемі їх зафарбовано) дорівнює $551 \mathrm{~m}^{2}$, то рівняння можна було скласти двома способами (1) та (2): 


$$
(3 x-5)(3 x+7)-2(3 x-5)=551
$$

$$
(3 x-5)(3 x+7-2)=551
$$

3 іншого боку, загальна площа ділянки під зоною 3 та зоною 4 (на схемі їх зафарбовано) дорівнює $220 \mathrm{~m}^{2}$, то ми можемо аналогічно скласти два рівняння (3) та (4) для знаходження невідомого коефіцієнта $x$ :

$$
(2 x-6)(2 x+12)-6(2 x-6)=220
$$

$$
(2 x-6)(2 x+12-6)=220(4)
$$

Кожне із рівнянь (1), (2), (3) і (4) мають однакові корені: 8 та -8 . Оскільки корінь -8 буде сторонній для наших зон прямокутної форми, то коефіцієнт $x$ прийматиме значення 8 на всіх визначених рівнянь. Знайшовши невідомий коефіцієнт, учні далі мають змогу втілювати всі додатково поставлені завдання проєкту.

Ключі до задачі: загальнаплоща парку становить 3120 м²; по периметру об'єкта можна розмістити 52 берези. Кількість лавочок та сміттєвих баків може варіюватись в залежності від розміщення.

Математичні розрахунки допомагають учням набути навички практичного розуміння необхідності вивчення формул для розв'язки реальних задач, а робота в групах готує їх до співпраці та проявів толерантності до чужих думок.

Інформатика. Не у всіх $33 \mathrm{CO}$ присутнє новітнє устаткування 3 3Dпринтерами для планування та побудови макету, але мережа Інтернет $є$ в кожного учня. В світовій павутині $є$ велика кількість безкоштовних програм для 3D-планування дизайну екстер'єру. Наприклад, у роботі над проєктом можна використати такі програми: GardenPlanner, X-Designer, SketchUp, RealtimeLandscapingArchitect, CompleteLandscapeDesigner 3 та інші.

Планування екстер'єру для дітей в електронному вигляді буде нагадувати гру, хоча вони будуть займатися копіткою працею. Електронне планування дозволить проявити учням всю свою фантазію стосовно комфортного облаштування парку відпочинку у ході групового обговорення.

Образотворче мистецтво. За допомогою знань із цього предмету учні зможуть із легкістю зобразити на схематичному плані основні та додаткові елементи парку. Навички малювання стануть у нагоді при зображенні та розстановці всіх елементів об'єкту на аркуші паперу. Побудову основних та додаткових зон, доріжок, споруд та природних ландшафтів можна здійснювати за допомогою виділенням кольорами або різними штриховками.

Таким чином, оформлення проєкту супроводжується розвитком креативного та критичного мислення учнів, котрі вчаться генерувати ідеї та перегруповувати їх, відбувається синтез науки і мистецтва. 
Трудове навчання. Під час виконання реального макету парку, діти можуть втілювати знання технологій розробок макетів та моделей, добирати найбільш доцільні матеріали для використання. Для побудови 3D-моделі та реального макету, учні згадують поняття масштаб та правила масштабування.

Здобувачі освіти мають можливість не просто заучувати необхідну послідовність дій та теоретичні засади технології, а проходити кожен крок алгоритму на практиці. Шляхом проб і помилок учні знаходять максимально раціональний інженерний підхід до кінцевого результату поставленого завдання.

Біологія, хімія та екологія. Однією з глобальних проблем світу є питання вирубки лісів. Відповідно до якої залишається відкритим і питання забезпечення кисню та поглинання вуглекислого газу на планеті. Отже, діти матимуть змогу на прикладі маленького парку дослідити питання озеленіння планети. Отримані розрахунки дадуть змогу оцінити користь висадки дерев у глобальному масштабі. Також не менш важливим питанням для дослідження буде проблема забруднення повітря та один із способів його очищення, а саме - озеленіння. Робота промислових підприємств, забруднення повітря автомобілями, великі звалища сміття - все це негативно впливає на якість кисню на планеті. Порушені питання змушують дітей задуматись над відповідальністю перед природою.

Апробація проєкту в навчальній діяльності. Проєкт було виконано учнями 8 класу. Вирішення поставленого завдання сприяло активному обговоренню ходу виконання задачі в кожній групі. Учні, за допомогою математичних розрахунків, із легкістю отримали всі необхідні значення. Подальший розвиток проєкту проходив відповідно до плану, сформульованого в завданні та розширеного в ході діалогу.

Учитель у цьому проєкті виконує роль фасилітатора, який організовує успішне групове обговорення поставленої задачі та забезпечує максимальне залучення всіх учнів до процесу виконання завдання. Педагог також здійснює технічну підтримку, підказує доступні програмні ресурси для побудови 3D-моделі парку. Саме в цьому виникали основні труднощі у дітей.

Під час виконання проєкту учні не просто отримували готові відповіді до задачі, а мали змогу використовувати свої знання, щоб знайти цю відповідь самостійно. Побудова моделей та макетів сприяла розвитку фантазії учнів, надаючи їм можливість розкрити творчій потенціал.

Обговорення. Враховуючи напрацювання О. Янковської, О. Патрикеєвої, Т. Андрущенко, С. Буліги, В. Камишина, Л. Ніколенко, Е. Клімової з питань аспектів реалізації STEM-освіти та мотивації учнів до 
науково-дослідної діяльності, плануємо спрямувати подальші дослідження на визначення основних складових STEAM-орієнтованого підходу при оволодінні учнями знаннями з предметів природничо-математичного циклу.

Висновки. Таким чином, інтегрований практично-орієнтований підхід до отримання знань та навичок у форматі STEM-освіти усуває розрив між теоретичними знаннями та їх практичним втіленням. У процесі навчання учень не просто сприймає інформацію, а генерує цікаві ідеї та відразу втілює їх у життя, навчається планувати свою діяльність, виходячи 3 поставленого завдання i наявних ресурсів. STEM-освіта забезпечує цілеспрямоване створення зв'язків між навчальним процесом і викликами сучасного світу в аспекті розвитку природних здібностей учня. Практично-орієнтований спосіб отримання знань та навичок у контексті STAEM-проєкту - це процес творчого пошуку раціональних рішень поставленого завдання.

\section{ЛІТЕРАТУРА:}

Hallinen J. STEM education curriculum [Електронний pecypc]. Encyclopedia Britannica. Режим доступу : https://www.britannica.com/topic/STEM-education

TeachingSTEM [Електронний ресурс]. Режим доступу: https://teach.com/what/teachersknow/stem-education

Science, Technology, Engineering, and Math, including Computer Science [Електронний pecypc] / U. S. Department of Education. Режим доступу : https://www.ed.gov/stem

Глосарій [Електронний ресурс]. Державна наукова установа «Інститут модернізації змісту освіти». Режим доступу : https://imzo.gov.ua/stem-osvita/glosariy

Мазорчук М. Національний звіт за результатами міжнародного дослідження якості освіти PISA-2018. Український центр оцінювання якості освіти. К. : УЦОЯО, 2019. С. 249

Проект концепції STЕM-освіти в Україні [Електронний ресурс]. Режим доступу : http://mk-kor.at.ua/STEM/STEM_2017.pdf

Освітні програми [Електронний ресурс]. Міністерство освіти і науки України. Режим доступу : $\quad$ https://mon.gov.ua/activity/education/zagalna-serednya/navchalniprogramy.html

Поліхун Н. І. Упровадження STEM-освіти в умовах інтеграції формальної і неформальної освіти обдарованих учнів : метод. рек. К. : Інститут обдарованої дитини НАПН України, 2019. 80 с.

Сінопальнікова Н. М. Педагогічні умови підготовки майбутніх учителів до застосування інтегрованих форм організації навчального процесу в початковій школі: автореф. дис. на здобуття наук. ступеня канд. пед. наук : 13.00.04 / Харківський національний педагогічний університет імені Г. С. Сковороди Х., 2010. 20 с.

\section{REFERENCES:}

Hallinen, J. (2015). STEM education curriculum. Encyclopedia Britannica. Retrieved from https://www.britannica.com/topic/STEM-education

Teaching STEM (n. d.). Retrieved from https://teach.com/what/teachers-know/stem-education

Science, Technology, Engineering, and Math, including Computer Science (n. d.). U.S. Department of Education. Retrieved from https://www.ed.gov/stem 
Glossarii (n. d.). Derzhavna naukova ustanova «Instytut modernizatsii zmistu osvity». [State Scientific Institution "Institute of Education Content Modernization"]. Retrieved from https://imzo.gov.ua/stem-osvita/glosariy (in Ukranian)

Mazorchuk, M., Vakulenko, T., Tereshchenko, V., Bychko, H., Shumova, K., Rakov, S., Horokh, V. \& al. (2019). Natsional'nyi zvit za rezultatamy mizhnarodnoho doslidzhennia yakosti osvity PISA-2018. [National Report on the results of international study of PISA-2018 education]. Kyiv : Ukrainian Center for Education Quality Assessment. 249 (in Ukranian)

Proekt kontseptsii STEM-osvity v Ukraini (n. d.). [Draft Concept of Stem Education in Ukraine]. Retrieved from http://mk-kor.at.ua/STEM/STEM_2017.pdf (in Ukranian)

Osvitni prohramy (n. d.). Educational programs. Ministry of Education and Science of Ukraine. Retrieved fromhttps://mon.gov.ua/activity/education/zagalna-serednya/navchalniprogramy.html (in Ukranian)

Polikhun, N. I., Postova, K. H., Slipukhina, I. A., Onopchenko, H. V. \&Onopchenko, O. V. (2019). Uprovadzhennia STEM-osvity v umovakh intehratsii formalnoi $i$ neformalnoi osvity obdarovanykh uchniv [Implementation of STEM education in the context of integration of formal and non-formal education of gifted students] : manual. Kyiv : Institute of Gifted Child of NAPS of Ukraine (in Ukrainian)

Sinopalnikova, N. M. (2010). Pedahohichni umovy pidhotovky maibutnikh uchyteliv do zastosuvannia intehrovanykh form orhanizatsii navchalnoho protsesu v pochatkoviy shkoli [Pedagogical conditions of training prospective teachers for using integrative forms of teaching process organization in primary school] (Abstract of candidate's thesis, G. S. Skovoroda National Pedagogical University). Kharkiv, Ukraine (in Ukranian).

\begin{tabular}{|c|c|}
\hline Інформація про авторів: & Information about the authors: \\
\hline Матвійчук Юлія Юріївна, & Matviichuk Yuliia Yuriivna, \\
\hline $\begin{array}{l}\text { ORCID: http://orcid.org/0000-0002-8003- } \\
\text { 5259, аспірантка кафедри освітології та }\end{array}$ & $\begin{array}{l}\text { ORCID: http://orcid.org/0000-0002-8003- } \\
\text { 5259, Graduate student of the Department of of }\end{array}$ \\
\hline інноваційної педагогіки Харківського & Education and Innovative Pedagogy H. S. \\
\hline національного педагогічного університету & Skovoroda Kharkiv National Pedagogical \\
\hline $\begin{array}{l}\text { імені Г. С. Сковороди, вул. Валентинівська, } \\
2, \text { м. Харків, Україна, } 61166\end{array}$ & $\begin{array}{l}\text { University, Valentynivska } \\
\text { Ukraine, } 61166\end{array}$ \\
\hline e-mail: YuliiaMatvii@i.ua & e-mail: YuliiaMatvii@i.ua \\
\hline
\end{tabular}

DOI: $10.34142 / 23128046.2021 .50 .11$

Дата надходження статті до редакції: 25.02.2021 p.

Стаття прийнята до друку: 11.03.2021 p. 